\title{
Application of hierarchical method and fuzzy AHP-TOPSIS method for multi-criteria decision making in financing
}

Elham Soleimani ${ }^{1}$, Mohaddeseh Dehyadegari ${ }^{2 *}$, Hassan Zarei Gerami ${ }^{3}$

$\mathrm{PhD}$ student, Systems Optimization Engineering, Department of Industrial Engineering, Kish

International University, $\operatorname{Iran}^{1 *}$

Master, Industrial Management, Faculty of Management, Hormozgan University, Bandar Abbas, Iran ${ }^{2}$

Professor, Department of Industrial Engineering, Faculty of Engineering, Payame Noor Central

University, Assaluyeh Special Zone, Iran ${ }^{3}$

elham.Soleimani@gmail.com ${ }^{1 *}$, m.dehyadegari900@gmail.com ${ }^{2}$, h.zarei.g@gmail.com ${ }^{3}$

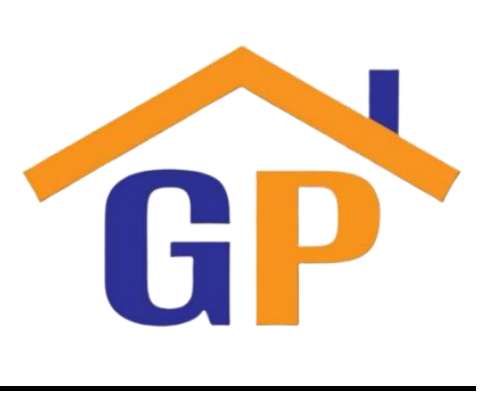

Article History

Received on 14 April 2021

$1^{\text {st }}$ Revision on 21 April 2021

$2^{\text {nd }}$ Revision on 23 April 2021

$3^{\text {rd }}$ Revision on 7 May 2021

Accepted on 11 May 2021

\begin{abstract}
Purpose: One way to make more profit in different companies is to choose the right method of financing. While the impact of financial structure on the economic structure is so important that today they believe that economic growth cannot be achieved without an efficient financial sector. The method of financing is financial. At first, in this study, the fuzzy Delphi method (Delphi) has been used in order to identify the factors and criteria of supply.
\end{abstract}

Research methodology: The absorption of foreign capital has been identified as a method of financing. For this purpose, in this research, AHP hierarchical analysis method is used.

Results: In this article, the application of fuzzy AHP - TOPSIS method for the problem of financing is investigated. The process of managing financial resources is one of the reasons for allocating its technical equipment to various applications in this company.

Limitations: However, the results of our studies show that although a set of known values in this company, the financing process may not adhere strongly to these values. Emphasis on evaluation aspects - changes in various areas that indicate local values may also affect the supply trend.

Contribution: Multi-criteria decision methods are useful in that they provide a basis for analyzing and transforming complex and complex problems into simpler ones. In that framework, the planner can easily evaluate the options with the help of criteria and sub-criteria. Using these methods can help a lot in choosing the best available solution. Other advantages of these methods include flexibility, simplicity of calculations and the possibility of the final ranking of options.

Keywords: Financing, Hierarchical method, Multi-criteria decision making, Fuzzy AHP-TOPSIS

How to cite: Soleimani, E., Dehyadegari, M., \& Gerami, H. Z. (2021). Application of hierarchical method and fuzzy AHPTOPSIS method for multi-criteria decision making in financing. Annals of Management and Organization Research, 1(4), 307-317.

\section{Introduction}

The success of organizations and gaining competitive advantage. In fact, the nature of the supplier selection process is a multi-criteria issue that occurs in an environment with insufficient information; Therefore, in order to evaluate and select the appropriate suppliers of the organization, we need to use methods that are effective in such environments (Sabetmotlagh \& et al., 2014). Companies have 
access to various financial resources to implement available profitable investment projects, settle overdue debts, increase working capital, and pay dividends to shareholders. These resources include cash from operating activities. And sales of assets (as sources within the financing organization), borrowing and banking, issuance of corporate bonds, and issuance of new shares as sources of the financing organization). The ability of companies to determine the right financial resources and make the right decision in this regard is one of the main factors for the company's success. The most important goal that management should consider when choosing a financing method is different financing. And its effects on the company's returns and risk, choose resources that minimize financing costs. The proper combination of sources of financing is associated with features such as low capital costs and higher rates of return. Iran's economy faces two major problems: poverty and unemployment, and government efforts alone have so far failed to be effective. Unemployment must be eradicated, and unemployment must not be allowed to continue in the future. Providing financial resources, both for the daily needs and daily needs of the family and for investment and increased production, is essential. It is very important. The main point here is that it is not possible to meet these needs easily and in the fastest time. In such cases, it is necessary to use micro-financing methods to solve the above-mentioned problems in the fastest time. (Mohajerani, 2003).

The effect of government spending and its sources of financing on GDP and economic growth is one of the important issues in economic discussions and analysis (Qatmiri et al., 2006). This is while financing and its methods are among the most important challenges in the supply and resources of public and private centers in Iran and different financing methods and their impact. In economics, cooperatives are the questions that have always been raised in this field. In general, the main goal of companies and non-profit organizations is to make more profit, followed by increasing the wealth of shareholders and the price of shares of the institution. One of the most profitable ways to choose is to choose the appropriate method (Taghavi and Zamanian, 2009). While the impact of financial structure on economic structure is so important that today they believe that without having an efficient financial sector, economic growth cannot be achieved (Reza, 2010). Companies when they need financial resources Newcomers can either obtain the desired funds through borrowing or obtain the required funds by transferring part of the company's ownership. In the meantime, the need to consider the cost of different financing sources and the effects each of these sources has on returns and operational risk (Taghavi and Zamanian, 2009). Companies in financing decisions, with two sources of financing internal and external ExternalForeign finance sources, including cash flows from operating activities, sales, assets, and accumulated profits, and external resources, including funds generated through the financial market, such as the issuance of equity securities, issuance of new shares and receipt of financial facilities from the bank (Kurdestani and Najafi Emran, 2010). In order to study the methods of financing in cooperative and consumer stores, first, appropriate criteria should be evaluated. To identify its weaknesses and strengths, we will first identify the effective internal organizational factors of resource absorption, then place the indicators to distinguish each of these factors. We will act on each other and prioritize them, which will be used for this purpose by experts and experts in the field of financing in companies. The method used in this research is the hierarchical analysis process (AHP). In this study, we try to use a combination of AHP and TOPSIS hierarchical analysis methods to examine more accurately the methods of financing through the private sector for financing in cooperatives and consumption of Fajr Jam Petrochemical Company.

\section{Literature review and hypothesis development Capital structure and its importance}

The capital structure of companies plays a decisive role in investment decisions. Deciding on capital structure is one of the most challenging and complex issues for companies to move forward and, at the same time, the most vital decision about their survival. By referring to research and academic texts, it is seen that the main reasons for company failure. Most small business owners do not have strong business skills and thus have a correct understanding and inference of the conditions and mode of operation of financial markets and resource suppliers. For example, the owners of these companies may choose the wrong combination of resources (debt versus capital) or may not have the resources to pursue high liquidity commitments and constraints for them. Or even enter into contracts that entail high-cost commitments. They may even turn to resource suppliers for financing that are difficult to 
work with. Therefore, existing weaknesses may lead to inadequate investment that threatens the survival of the company.

\section{Supply of resources}

Providing resources means maintaining the responsibility of the services of the organization and at the same time assigning those services to an external organization, which is usually done under a contract with strict standards, costs and conditions (Translators-Covenant Group, 2006). In fact, financing with finance, ie providing financial resources and funds to continue the activity of the company, creating and launching projects to develop and generate income for these economic units, financing mainly through the issuance of shares, sale of bonds and loans. And credit is taken.

\section{Profit management and capital structure}

One of the most controversial issues facing companies, which is also the most critical decision about their survival, is deciding on capital structure and determining the factors affecting it. On the other hand, profit management is considered one factor affecting the capital structure in corporate governance issues. Profit management occurs when managers use their personal judgments in financial reporting and manipulate the structure of transactions to change financial reporting. Since the capital structure of companies consists of the rights of owners to enjoy their future benefits and sources of financing, which include long-term debt, ordinary and preferred stock, and accrued profits, change reporting Financial $\neg$ Determining and changing the structure of transactions can lead to changes in the capital structure. Decisions related to the capital structure will play an influential role in the efficiency and credibility of companies with investment institutions (Ali Aghaei et al., 2009). Earnings management sometimes creates certain trades for managers so that profits seem desirable at the end of the year.

\section{Capital structure and profit quality}

There are two very important topics in finance and accounting. Capital attention Investors in these two areas can be of great help to them in order to invest properly. A significant relationship between debt to asset ratio and other indicators that somehow affect the capital structure. There is no impact on profit quality. Also, the capital structure has a positive relationship with the ownership structure and also the existence of a negative relationship between the number of shares owned by institutional investors and leverage was confirmed (Alam al-Huda et al., 2015).

\section{Company size and capital structure}

From a theoretical point of view, the relationship between firm size and leverage is not clear. Based on the static equilibrium model, larger firms have greater borrowing capacity and can earn more profits. Larger firms also tend to be more diverse and therefore have more stable cash flows, which stabilize their cash flow, reducing their risk and bankruptcy. They also have more bargaining power when using debt. They can reduce transaction costs by issuing long-term debt. Another possibility is that larger companies have more diverse shareholders, which results in less control over the company's management. Therefore, it is possible for managers to reduce risk. Use the debt's personal language resulting from bankruptcy. However, when company size is considered as a substitute variable for default risk, where the costs of financial turmoil are insignificant, there should be no significant positive relationship between leverage and company size (Kurdistani and Najafi Emran, 2008).

\section{Profitability and capital structure}

High-profit companies have more capacity to finance projects through internal resources than lowprofit companies. Accordingly, there is a difference between profitability and value for money. The company has a negative relationship (Mehrani and Rasaeian, 1999)

\section{The structure of financial security in the economy: cost-income ranking}

The budget is financed through various methods. Which method of financing has the least cost for the national economy? Government revenue is provided from non-renewable and non-renewable domestic sources or from non-budgetary sources (borrowing from inside and outside). Each is different in terms of economic value. Revenues generated by taxes and duties, sales, market services, and non-market renewables are among renewable income sources. Taxes are among the most 
extensive and general. Sources of income are renewable; in the public sector, compulsory contexts, without any legal claims against the payment of taxes, are made by the government. Income from non-renewable sources through the sale of oil and gas is sold. Currency and sales of other assets are obtained. The economic value of these resources is not equal and due to their monetary value rating, independent accounting is required. Non-budget revenue sources of borrowing from inside the bank Central and commercial and specialized banks are obtained by borrowing from the people by borrowing from abroad. Each of these methods of financing has different effects on the budget and the national economy. The government could not use its external resources by Renewable and nonrenewable modes; financing slowly borrows from the banking system. Over time, this method of financing is tied up in the form of existing debt and increases national debt in the economy. This type of financing increases. The money supply increases inflation and has a negative effect on the economy.

\section{Internal and external financial security}

In financing decisions, companies are faced with two sources: domestic and external. Internal financial resources include cash flows from operating activities, asset sales, and profits and resources. Foreigners have funds raised through financial markets, such as the issuance of bonds, the distribution of new shares, and the receipt of financial facilities from the bank. Managers must decide how to raise the funds they need and how to use the available financial resources. They can use these funds to pay dividends to shareholders, implement profitable investment projects, settle overdue payments, and increase working capital (Frank \& Goyal, 2003).

\section{Factors determining the structure of financial security}

Theoretically, managers' decisions about the optimal structure of financing are influenced by various factors such as political, economic and legal factors. Therefore, determining the strategy and structure of financing in addition to being affected by some variables Economic macroeconomics such as inflation, interest rates, lending policies in the banking system and taxation. Under the influence of factors such as financing costs, financial and commercial risk of companies, the combination of assets with contractual restrictions on absorption. Resources are located through debt creation and revision of stock exchange, securities laws.

\section{Financing and complete market pattern}

Many financial reviews require the assumption of a complete market. If the market is complete, contracts will be cost-free, which means that these resources can be accessed at no cost if re-assigned. In such a market, a company in any part of the world is able to receive the capital supplied by the resource providers, in which case the value of the company from the point of view of the capital providers is equal to the actual value of the company's cash flows. They are paid. In the presence of a complete market, all investors evaluate a particular project in the same way, and the cost of capital is the same in different countries.

\section{Financing in the event of deviation from the full market pattern}

In a full market, a company can easily finance its valuable project. But in practice, the assumption of a full market is violated for two main reasons. First, investors cannot observe all the activities performed by managers, and Second, managers have information that investors are denied access to. The reason with the first problem is called the problem of hidden activities and the reason with the second problem is called the problem of hidden information. These problems create the problem of representation between managers and investors (Dosineh et al., 2009).

\section{Sources of financing companies in Iran}

1. Rights of share holders

Fund

Capital includes funds that shareholders provide at the beginning of the establishment of the company. Capital has the highest cost and lowest risk for the company. Shareholders are the last people who share their profit from the company they take. 
Accumulated profit

This item represents the profits that the company has earned from its operations or other income and belongs to the shareholders who are not distributed among them. The amount, cost and risk of this type of financing is equal to the capital.

2. Debts

Deposits (trust fund)

Good interest loans are also divided into current and savings (Bahmani, 2000). This deposit is made by people who can use check services and makes up a large proportion of bank deposits. This type of deposit does not accrue any interest. However, in return for use of these deposits, the bank provides banking services to deposit holders, such as the issuance of checks, services related to the receipt and payment of checks.

Deposit good loan savings

This deposit is a sight deposit and the bank, as a trustee, maintains the deposit. In addition to providing services, the bank also awards prizes for these types of deposits.

Short-term investment deposit

In these types of deposits, the depositor gives the bank a power of attorney to use his deposit in the form of interest-free banking operations in the form of various contracts and to relate the obtained interests according to the relevant regulations and regulations. The conciliation fee between the bank and the depositor is not paid in proportion to the amount and period after deducting the proxy fee, and if the customer has given the extension fee to the bank, the extension will be the same with the coefficients. This deposit includes a short-term investment deposit. It is normal and special. In order to encourage depositors and attract customers, according to the decision of the Monetary and Credit Council, a short-term deposit account with a rate of $2 \%$ more than the interest on the account of shortterm investment deposits can be opened. The amount of these deposits is fixed throughout the deposit period and cannot be changed. The term of the special short-term investment deposit is 6 months from the date of issuance, and at maturity, if no written order is received from the depositor, it can be extended for subsequent periods of 6 months.

Special deposit to receive the facility

According to the Central Bank's license, to maintain the deposits of the applicants for using housing facilities, the banks will open an account called the housing purchase deposit. Applicants must deposit certain amounts with the bank for certain periods so that they can use the housing purchase facility., 2000). This method of deposit can be generalized for other types of facilities and occurs mainly in cases where the financial market is faced with increased demand for funds and the bank's resources do not meet the needs of facility applicants.

Long-term investment deposits

It includes deposits that the bank lends to investors on behalf of depositors as a lawyer and distributes the profits between itself and the depositor. These types of deposits are usually 1 to 5 years old and the bank Pays special interest on account for each of them. The depositor has no right to withdraw from the account during the contract period.

\section{Loans from the Central Bank}

It includes funds that the central bank provides to a specific bank (especially specialized banks) for the performance of specific purposes and by paying special facilities (mandatory facilities and managed funds).

Borrowing from the banking system

In order to achieve their goals and achieve greater profitability, banks borrow from other banks, so that they can use cheap resources to increase their profitability.

Managed funds

Management funds are funds provided to the bank by the organizations with institutions for specific purposes under certain conditions. 
Borrowing from a foreign exchange reserve fund

Banks and other institutions borrow from the Foreign Exchange Reserve Fund to achieve their goals and achieve profitability. To be able to use cheap resources to increase their profitability. According to the regulations approved by the Foreign Exchange Reserve Fund, banks can pay foreign currency repayment facilities to customers and applicants of foreign currency loans from this fund.

You have to pay

Includes bills that the bank must pay from its funds.

Bills Received

It is the bank that the bank takes from the customers and accepts and receives them.

Accepted and signed remittance

bank transfer that the bank writes in favor of customers to pay the amounts in bank transfer at maturity.

\section{Advantages of bank transfer}

Remittance can be considered a change in the human economic system. Let's take a look at some of the positives.

1.No need for direct money transfers

Once you have it, you will no longer need to transfer cash.

2.Increase security in transactions

When there is no cash, there is no stealing.

3.Convenience in exchange

The use of remittances boosts trade and the economy because of their simple mechanism.

4.Convenient storage

Undoubtedly, keeping 100 sheets of paper worth 10 billion tomans is much easier than keeping 10

billion in cash.

5.Increase the ability to create money

With the expansion of remittance use in transactions, the process of investing, making a profit, and making money became much more than ever. In fact, it is possible to rebuild credit with a single sheet of paper that only bears credit.

\section{Remittance usage problems}

Despite the great potential that remittances have given to traders, it still cannot be used blindfolded. Considering the weaknesses or problems that remittances have or create allows us to make smarter trades.

\section{Lack of transparency of remittance system}

Most remittances are not legally registered. On the other hand, those who are known as exporters can provide you with millions and even billions of remittances without even having a single rial. For this reason, the lack of transparency of this system can lead to problems such as fraud and loss of personal credibility.

\section{Low security in remittances}

Security and remittances are double-edged swords. Although we talked about security as a positive point in remittances a little earlier, due to the legal weakness of remittances, it is sometimes necessary to have a witness with us when issuing and receiving remittances.

\section{The emergence of counterfeit remittances}

Remittances are plain paper that fraudsters can easily manipulate and give you counterfeit samples.

Having a fake book is no different from holding a piece of scribbled paper. 


\section{Real devaluation Remittances over time}

Over time, the value of countries' currencies increases or decreases. As a result, the value of remittances goes up and down.

So far, research that has examined and prioritized in-store financing methods has no research history, and most of the research has been reviewed in other statistical communities, some of which are described below:

Abolfathi et al (2013) conducted a study to examine the methods of financing for rail transport projects and provide executive solutions. Using a comparative comparison with other countries, a suitable model for financing the sector Iran has been presented in this study. Different methods have been proposed for financing for the sectors of railway infrastructure development, fleet development, and exploitation development. The method should be used for railway infrastructure because the government still owns it in Iran. To be used to reduce risk in the end to the ownership of the government. PPP contracts, which are public-private partnerships, have been proposed for this sector. For the fleet development sector, leasing and sukuk contracts have been proposed, and the best way to develop the operation is to use the employee savings fund and the private sector lease model. With government ownership, the government has suggested developing public service equipment and facilities through public participation (selling bonds with other policies).

Sharafi and Fatehi (2011), in a study entitled "The role of branch management in achieving the goals of state-owned banks and related challenges," examined the role of branch managers in the bank's performance and concluded that bank branches as the main components of the organization, they play a key and undeniable role in achieving the relevant goals. Considering that the branch managers as organizational, operational managers have the task of managing the affairs related to these units through the performance of planning, organizing, They are responsible for mobilizing resources and facilities, guiding, leading and controlling them within the framework of technical, human and perceptual skills, so special attention and attention from senior organizational managers to perform organizational roles and missions optimally and effectively is of special importance.

Mollanazeri et al. (2010) conducted a study to investigate the relationship between financing methods (external resources and the success and failure of companies listed on the Tehran Stock Exchange. This study investigates and understands the relationship between methods of financing (an increase of capital and bank loans with the company's success and failure of the company has been done. The sample includes 624 companies, 99 of which have provided financing from 67 successful companies and 32 unsuccessful companies) and 525 companies from the bank loan area. (177 successful companies and 348 unsuccessful companies) show a significant relationship between financing methods and the success and failure of companies listed on the Tehran Stock Exchange and more capital increase than loans. Banking affects the success of companies. In other words, the number of successful companies that have financed through capital increase is more than all successful companies in this group, which are funded through bank loans.

Morteza Jafarzadeh and Mina Najjar (2010), in a study entitled "Financing through the issuance of participation bonds; opportunities and threats" in which they examined the method of financing, concluded that many tissue renovation projects Worn out in different cities of the country, due to lack of sufficient financial resources were regularly postponed.

Razani (2003), in his dissertation entitled "Study and introduction of new and effective methods of attracting financial resources in the branches of Tejarat Bank of Lorestan province to study the factors affecting the attraction of financial resources in TejaratBanking Group in Lorestan province such as: providing easier facilities, Favorable physical space, revision of the method of awards, importance for the customer, appropriate rules and regulations, attracting long-term resources and also to examine the level of competitiveness between the country's banking groups, to examine the trend of monetary variables during the period ( 1994-2014) and also the performance of the bank with other banking groups.In this research, descriptive survey method has been used. 
Ruhling, (2005), in a study of the income structure of municipalities in developing countries, shows that property tax is the most important type of local tax and more than 130 countries in the world receive it. This tax can serve the broader goals of local accountability and bring the effective relationship between municipal services and their financial resources closer together. Liu \&Hung(2006) studied long-term profitability in Taiwanese banks and concluded that banking services are the most important factor in profitability and profitability for the studied bank branches. In addition, bank employees are the most important and fundamental factor in achieving increased profitability and profit.

As mentioned earlier, equipping and allocating resources and providing other banking services to customers in line with the bank's goals are the most important activities of a branch. While affecting the competitive power of each bank in comparison with other banks, the mentioned activities cause them to play a significant role in achieving the economic goals of the government and in terms of the small role of the capital market in the country's economy is doubly important. Uncertainty of the performance of each branch regarding each of the mentioned activities, if it is not accompanied by proper planning and control by the branch manager, can impose various credit, operational, reputation, liquidity, etc. risks on the bank with Face major challenges. Therefore, the branch manager has a key and fundamental role in order to properly combine and use the production factors of the branch in order to perform optimal banking activities, and any weakness in this regard, while creating challenges and problems for that branch, can according to the principle in Mino will spread it to other branches of the bank and create a crisis for the whole organization. Therefore, it is necessary for the senior management of the organization to have adequate and appropriate supervision and control over all activities and affairs of this department and by using the necessary equipment and allocating sufficient budget, incentive and monitoring tools to control and improve the performance of these units to operate.

\section{Research methodology}

The results of this section showed that the factors are efficiency, cost, stability, operation., Justice and transparency have been the most important criteria for choosing the method of financing, as well as the formation of cooperatives, receiving facilities, issuing bonds, creating investment companies, presence in the stock market, creating a plan as a shareholder and Finally, the absorption of foreign capital has been identified as a method of financing. For this purpose, in this research, AHP hierarchical analysis method is used.

The conceptual model of this research is presented in the following figure. The first series shows the purpose of the research, the second series shows comparative factors and the third series shows the options being evaluated. 

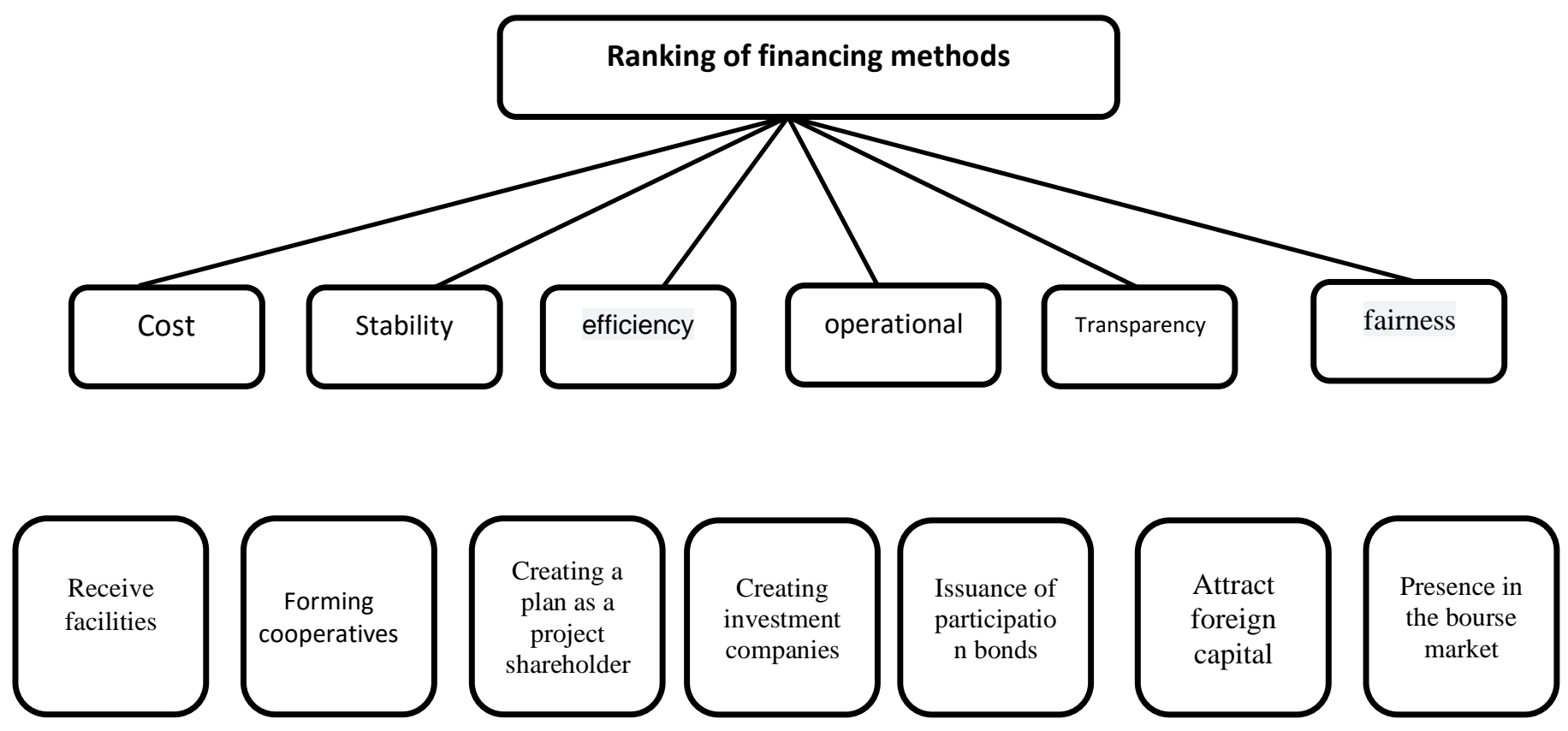

Figure 1. Hierarchical model

\section{Results and discussion}

The importance of developing the financial sector and the subsequent development of the country's financing stems from the fact that an efficient financial sector plays a key role in equipping resources for investment, encouraging the inflow and outflow of foreign capital, as well as optimizing the resource allocation mechanism and a financial system. Developed in a country with proper financing for the real sector of the economy creates good economic growth and development opportunities. The capital structure of enterprises and how to combine financing between the debt market and the capital market is also very important. Capital structure decisions are affected by the risk of financing costs and the provision of appropriate returns. Financial resources can be used for domestic production and investment development if people benefit from an efficient financing system. This is not possible without the support of financial markets, especially the capital market (Ebadi \& Golmohmmadi, 2019). Efficiency, cost, sustainability, operationally, fairness, and transparency factors have been the most important criteria for choosing the financing method and forming cooperatives, receiving facilities, issuing participation bonds, creating investment companies, and participating in the stock market creating a plan. Shareholder and ultimately attracting foreign capital have been identified as financing methods.

The results of this study showed that efficiency has been identified as a major component in financing. Therefore, it is suggested to pay special attention to the efficiency component in order to choose the appropriate financing method. In the meantime, the financing method must be such that it leads us to provide the financial resources needed to equip the stores at the lowest cost. This can be done by studying different financing methods and their cost and benefits. In the research components section, cost has been identified as an important indicator in reviewing financing methods. Therefore, in choosing the appropriate financing method, it should be done in such a way that the costs of obtaining financial resources in the implementation of required projects are defined to a minimum and optimally. Sustainability is also one of the components for choosing the financing method. It is necessary for managers and planners within the organization to act properly to plan for proper financing so that they pay attention to the long-term effects of choosing the financing method. Have operational power. For example, choosing a method that cannot be done can cause many problems. 


\section{Conclusion}

The operational power of financing is of great importance both in the infrastructure sector and companies' financial ability and manpower. In choosing the financing method for the studied departments, it is necessary to have a suitable distribution for financial resources in different organizational departments and different departments. In this case, the financial resources will be distributed fairly among the different departments. In financing, it is necessary to have high transparency in the information sector because the more transparent the information in these sections, the greater the motivation of people to invest in stores. The research results in the prioritization of financing methods show that among the financing methods are forming cooperatives, receiving facilities, issuing participation bonds, creating investment companies, participating in the stock market, creating a plan as a shareholder, and finally attracting capital. Foreigners have the highest and lowest priority among financing methods, respectively.

\section{References}

Abolfathi, F. Hasheminejad. S M, Ebrahimi, S B. (2013). Financing methods in intra-city rail transportation, sixth conference on financing development in Iran. Tehran.

Alam al-Huda, Seyyed Sajjad, Daryabar, Abdullah, Tarighi, Samaneh. (2015). Investigating the relationship between profit quality and capital structure (Case study: non-financial companies listed on the tehran stock exchange). Financial Economics, 8 (27), 1-10.

Ali Aghaei, M. Javan. A., NazlakiArdakani, M. and Mousavi, A. (2009). Study of the effect of earnings management, company size and profitability ratios on capital structure, accounting studies. 25,104-87.

Bahmani,A. (2000). A Study of mudaraba contract and its performance in commercial banks of the country. Magazine: Bank and Economy,10,34-38.

Dasineh,M,Ahadi,NooriFardi.(1388). Evaluating the relationship between financing structure and decisions related to investing resources in the assets of companies listed on the Tehran Bourse Exchange. Researcher, 16,18-29.

Dosineh, Mehdi; AhadiSarkani, Seyed Yousef; Nouri Fard, Yadollah. (2009). Assessing the relationship between the financing structure and decisions related to investing resources in the assets of companies listed on the Tehran Stock Exchange. Winter, 16, 18 -29.

Ebadi.RA,Golmohmmadi.T. (2019).Evaluate the relationship between the structure of the economy and capital market financing. Mieaoi. 8 (27), 27-45.

Frank, M. Z., \& Goyal, V. K. (2003). Testing the pecking order theory of capital structure. Journal of Financial Economics, 67(2), 217-248

Group of translators of the Covenant of Managers. (2006). Decision-making on outsourcing. Management Journal, 15, 38-41

Jafarzadeh, Morteza and Mina Najjar. (2010). Financing through the issuance of participation bonds; opportunities and threats (case study: plan to renovate and improve the worn-out texture around the holy shrine of HazratReza).

Kurdistani, Gh and Najafi Emran, M. (2008). Study of determinants of capital structure: an experimental test of static balance theory vs. coherent hierarchy theory. Financial Research, 1, 52.

Kurdistani, Gholamreza and Najafi Emran, Mazaher. Investigating the impact of financing methods on future return on stocks. Journal of Accounting Advances, Shiraz University, 2, 75-108.

Liu, Y. C., \& Hung, J. H. (2006). Services and the long-term profitability in Taiwan's banks. Global Finance Journal, 17(2), 177-191.

Mehrani, S. and Rasaeian. (2007). Study of the relationship between profitability ratios and capital structure in Tehran Stock Exchange. Accounting Studies, 81. 10-1.

Mohajerani, M. (2003). Micro credit, the most effective method of financing the needy. Bank and Economy, 40, 140.

Mollanazeri , M, Hejazi, R, Sahraei, M. (2010). Investigating the relationship between financing methods (external resources) and the success and failure of companies listed on the Tehran Stock Exchange. Financial Accounting and Auditing Research, 2(6), 65-86. 
Qatmiri, Mohammad Ali, Karim Islam Lobian and Massoud Shirazi. (2006). Investigating the impact of government expenditures and its financing sources on gdp and economic growth: The Case of Iran (1972-1993). Quantitative Economics, 5-36

Razani, B. (2003). Review and introduction of new and effective methods of attracting financial resources in the branches of Tejarat Bank of Lorestan Province Master's thesis (Faculty of Basic Sciences, Azad University, Khorasgan Branch.)

Reza, Shiva (2005) The effect of long-term financing on economic growth and development in Iran. Agricultural Economics and Development, 33-65.

Ruhling, M. (2005). Institutional constraints on the property tax and semi-autonomous municipal tax agencies in peru. Land and Urban Policies for Poverty Reduction, 125.

Sabet Motlagh Mohammad, Salehi Sedghiani Jamshid, AyaziSeyed Ali, AbediniNaeini Mehdi. (2014). Evaluation and selection of strategic suppliers using the combined method of Analytic Hierarchy Process and Gray Topsis. (11)4, 117-110.

Sharafi ,F and Fatehi,ZM. (2011). The role of branch management in achieving the goals of stateowned banks and related challenges, http://www.banksepah.ir/upload/modules/articles/pdfs/66.pdf.

Taghavi, Mehdi and Zamanian, Alireza. (2009). Evaluation of off-balance sheet financing methods on stock prices and profits of companies listed on the Tehran Stock Exchange. Quarterly Journal of Quantitative Management Studies, 2, 10-1. 